\title{
Managing Forests and Water for People under a Changing Environment
}

\author{
Ge Sun ${ }^{1, *(D)}$, Kevin Bishop ${ }^{2}$, Silvio Ferraz ${ }^{3}$ and Julia Jones ${ }^{4}$ \\ 1 Southern Research Station, USDA Forest Service, Research Triangle Park, Raleigh, NC 27709, USA \\ 2 Sveriges Lantbruksuniversitet, Swedish University of Agricultural Sciences, SE-750 07 Uppsala, Sweden; \\ Kevin.Bishop@slu.se \\ 3 Forest Sciences Department—ESALQ/USP, University of São Paulo, Av. Padua Dias, \\ 11-Piracicaba/SP-13418-900, Brazil; silvio.ferraz@usp.br \\ 4 College of Earth, Ocean, and Atmospheric Sciences, Oregon State University, Corvallis, OR 97331-5503, USA; \\ Julia.Jones@oregonstate.edu \\ * Correspondence: ge.sun@usda.gov
}

Received: 12 March 2020; Accepted: 14 March 2020; Published: 17 March 2020

\begin{abstract}
The Earth has entered the Anthropocene epoch and forest managers are facing unprecedented challenges to meet multiple ecosystem service demands from forests. Understanding the complex forest-water relations under a changing environment must add a human dimension, and this is essential in the move towards sustainable forest management in the 21st century. This Special Issue contains 10 papers presented at a joint international forest and water conference in Chile in 2018. These studies provide global examples on new advancements in sciences in forest ecohydrology, watershed management, and ecosystem service assessment under various geographical and socioeconomic settings.
\end{abstract}

Keywords: forestry; ecohydrology; watershed management; global change; sustainability

Forests cover about 30\% of the Earth's land area, or nearly 4 billion hectares. Enhancing the benefits and ecosystem services of forests has been increasingly recognized as an essential part of nature-based solutions for solving many emerging global environmental problems today, including sequestering atmospheric carbon, controlling land degradation and soil erosion, and providing abundant clear water. The United Nations emphasizes that sustainable forest management in the UN Strategic Plan for Forests 2017-2030 (UNSPF) is an essential component of the implementation of the 2030 Agenda for UN Sustainable Development, the Paris Agreement adopted under the Framework Convention on Climate Change, the Convention on Biological Diversity, the Convention to Combat Desertification, the Forest Instrument (UNFI), and other international forest-related instruments, processes, commitments and goals. A core science to support forest management is understanding the interactions of forests, water, and people. These interactions have become more and more complex under climate change and its associated impacts, such as the increase in intensity and frequency of drought and floods, increasing population and deforestation, and a rise in global demand for multiple ecosystem services including clean water supply and carbon sequestration. Research is needed to improve our understanding of the tradeoffs and synergies among forest ecosystem services. Forest watershed managers have recognized that water management is an essential component of forest management. Global environmental change poses increasing challenges for managing forests and water towards sustainable development. New science on forest and water is critically needed across the globe. In particular, we need a better understanding of the role of people in forest water management, in various economic and social settings. 
The "International Forests and Water Conference 2018, Valdivia, Chile" (http://forestsandwater2018. $\mathrm{cl} /$ ), a joint effort of the 5th IUFRO International Conference on Forests and Water in a Changing Environment and the Second Latin American Conference on Forests and Water provided a unique forum to examine forest and water issues in Latin America under a global context. The conference promoted an exchange of understanding and experience from the realms of research, policy, and public involvement, through to the development of international research collaborations. The conference focused on the following themes that covered a series of emerging research topics in the forest and water research and management communities.

1. Forests and water: The role of arts, humanities, and communication

2. The 2030 agenda framework for forests and waters

3. Forest ecosystems, water and climate change adaptation

4. Forest certification, government policy and water resources

5. Ecosystem service tradeoffs involving water from native forests and plantations

6. Aquatic and riparian biodiversity: Forest ecosystem-stream connections

7. Social aspects of watershed management and monitoring

8. Agroforestry and water

9. Forest ecosystem restoration for aquatic ecosystem services

10. Forests in the food-water-energy nexus

11. Modeling and decision support systems linking forest hydrology, management, and policy

12. The Forest-Water Network: Planning tools

This book represents a collection of some of the peer-reviewed papers presented at the Conference that are published in a special issue in Forests (https://www.mdpi.com/journal/forests/special_issues/ Forests_Water). These studies cover a large physiographic gradient across major continents and climatic zones including the temperate rainforests in Chile [1-3] and the subtropical forests in Brazil [4] and South America; temperate rainforests [5] and boreal forests [6] in North America; and the large tropical Mekong River Basin in Vietnam [7], the Nenjian River in the boreal northeastern China [8], and the arid Loess Plateau in northern China [9], in east Asia. Five papers addressed issues of the effects of water quantity and quality of native forest buffers on dissolved organic matter in forested and agricultural watersheds in northwestern Patagonia [1]; effects of eucalyptus management on nutrient and sediments in small watersheds in Brazil [4]; effects of pine and eucalyptus plantation forests on water supply for large watersheds $\left(>200 \mathrm{~km}^{2}\right)$ in south central Chile [3]; effects of forests and wetlands on water yield, surface runoff and baseflow in northeastern China [8], and the combined effects of climate and afforestation on soil moisture in Loess Plateau of China [9]. Five papers addressed management issues: Managing headwater streams under climate change [5]; local communities' participation in watershed management [2]; the nexus of forests, water, and policy [10]; ecosystem services in the Mekong River Basin [7] and; risk assessment of wildland fires in Alberta, Canada [6]. In summary, worldwide studies clearly show that forests and water are intimately connected, and forest management policies must balance the tradeoffs of ecosystem services and adapt to global environmental changes in order to meet sustainable development goals.

Water has become an essential part of contemporary forest management practices that aim to maximize ecosystem services to people. Sustainable forest management has a clear human dimension and must fit local natural and socioeconomic conditions. We hope that the information presented in this collection gives readers a glimpse of the complexity and future challenges in forest and water management in selected regions of the world. We would like to thank the authors for sharing their research, and the reviewers and editors for their dedications that made this Special Issue a success.

Author Contributions: Writing-original draft preparation, G.S.; writing-review and editing, all authors. All authors have read and agreed to the published version of the manuscript.

Conflicts of Interest: The authors declare no conflict of interest. 


\section{References}

1. Becerra-Rodas, C.; Little, C.; Lara, A.; Sandoval, J.; Osorio, S.; Nimptsch, J. The Role of Streamside Native Forests on Dissolved Organic Matter in Forested and Agricultural Watersheds in Northwestern Patagonia. Forests 2019, 10, 595. [CrossRef]

2. Vargas, V.; Carrasco, N.; Vargas, C. Local Participation in Forest Watershed Management: Design and Analysis of Experiences in Water Supply Micro-Basins with Forest Plantations in South Central Chile. Forests 2019, 10, 580. [CrossRef]

3. Alvarez-Garreton, C.; Lara, A.; Boisier, J.; Galleguillos, M. The Impacts of Native Forests and Forest Plantations on Water Supply in Chile. Forests 2019, 10, 473. [CrossRef]

4. Rodrigues, C.; Taniwaki, R.; Lane, P.; Lima, W.; Ferraz, S. Eucalyptus Short-Rotation Management Effects on Nutrient and Sediments in Subtropical Streams. Forests 2019, 10, 519. [CrossRef]

5. Olson, D.; Burton, J. Climate Associations with Headwater Streamflow in Managed Forests over 16 Years and Projections of Future Dry Headwater Stream Channels. Forests 2019, 10, 968. [CrossRef]

6. Robinne, F.; Bladon, K.; Silins, U.; Emelko, M.; Flannigan, M.; Parisien, M.; Wang, X.; Kienzle, S.; Dupont, D. A Regional-Scale Index for Assessing the Exposure of Drinking-Water Sources to Wildfires. Forests 2019, 10, 384. [CrossRef]

7. Netzer, M.; Sidman, G.; Pearson, T.; Walker, S.; Srinivasan, R. Combining Global Remote Sensing Products with Hydrological Modeling to Measure the Impact of Tropical Forest Loss on Water-Based Ecosystem Services. Forests 2019, 10, 413. [CrossRef]

8. Li, F.; Zhang, G.; Li, H.; Lu, W. Land Use Change Impacts on Hydrology in the Nenjiang River Basin, Northeast China. Forests 2019, 10, 476. [CrossRef]

9. Zhang, Q.; Wei, W.; Chen, L.; Yang, L. The Joint Effects of Precipitation Gradient and Afforestation on Soil Moisture across the Loess Plateau of China. Forests 2019, 10, 285. [CrossRef]

10. Springgay, E.; Casallas Ramirez, S.; Janzen, S.; Vannozzi Brito, V. The Forest-Water Nexus: An International Perspective. Forests 2019, 10, 915. [CrossRef]

(C) 2020 by the authors. Licensee MDPI, Basel, Switzerland. This article is an open access article distributed under the terms and conditions of the Creative Commons Attribution (CC BY) license (http://creativecommons.org/licenses/by/4.0/). 